\title{
Parent Engagement in Youth Drug Prevention in Chinese Families: Advancement in Program Development and Evaluation
}

\author{
Sandra K. M. Tsang \\ Department of Social Work and Social Administration, Faculty of Social Sciences, \\ The University of Hong Kong, Hong Kong \\ Received 12 October 2010; Revised 15 February 2011; Accepted 16 August 2011 \\ Academic Editor: Joav Merrick
}

The escalating youth drug abuse problem in Hong Kong has attracted intense attention from the government, schools, and youth service professionals. Most preventive efforts have focused directly on positive youth development, very often through school programs delivered to secondary school students. There have been limited efforts to engage parents even though it is obvious that the family is actually the primary context of children and youth development. This paper will assert the importance of parental engagement in youth drug-prevention work, discuss some barriers in such parental involvement, present some promising local attempts and their strengths and limitations, and propose that sustained efforts are needed to build up theory-driven and evidencebased resources for Chinese communities on the subject.

KEYWORDS: Chinese family, parent engagement, program development and evaluation, youth drug prevention 


\section{INTRODUCTION}

Findings from various studies conducted by the government, universities and nongovernmental organizations (NGOs) show that the youth drug problem in Hong Kong is escalating [1-3]. There is also normalization of drug use [4] and a surge in female drug users [5, 6]. These have drawn growing attention from key community stakeholders, like the government, schools, and youth service organizations. To combat the situation, positive youth development programs solely targeting adolescents and mainly conducted in schools have been the priority. This is certainly a correct way forward. Young people should be helped to take charge of their own healthy development, and since peers harbor both risky temptations and protective buffers in youth development, it is important to reduce the former and expand the latter.

In conjunction with the continued promotion of positive youth development [7] through schools and social services, there is an increasing awareness that the role of parents/families has been overlooked. The family is actually the primary physical, psychological, social, and spiritual setting which nurtures children into independent social members of society. Family education, conveyed through parents' formal and informal teaching, is the main means of such socialization. There is, however, a persistent underinvolvement of parents in the fight against youth drug use. A review of preventive education and publicity projects in Hong Kong from 1999 to 2009 showed that only about $10 \%$ of such programs took parents as their primary concern [8]. This paper will review key local experience in developing, delivering and researching parental engagement in antidrug work to advocate for more theory-driven and evidence-based resources on the subject in Chinese communities.

\section{IMPORTANCE OF PARENTAL ENGAGEMENT}

The importance of parental engagement in youth antidrug work can be demonstrated through key social science theories, overseas studies, local barriers to parents showing concern over the topic, and changing patterns of expressed needs from parents.

Three important theories highlight the important role of parents in antidrug campaigns. The Ecological Systems Theory [9] classified the social context into microsystem, mesosystem, exosystem, macrosystem, and chronosystem. This provides a conceptual framework for understanding the interactions between different domains and convincingly highlights the fact that parents and family systems occupy the next closest social systems beyond an individual. Parents play critical and irreplaceable roles in any child's development. The Social Development framework [10, 11] points out that the parent and family system harbors both protective and risk factors which impact children. Common family protective factors include protection, provision, and positive teaching, while indulgence and abusive parental behavior are common risk factors that hinder a child's healthy development. The framework shows that removing risk factors does not mean that protective factors will naturally emerge. Ensuring adequate basic means of living, and the essential parenting skills of communication, problem-solving, and conflict management are all important for building up protective factors. Finally, the Public Health approach [12,13] helps to highlight that families with no problems still need input for problem prevention (universal level), families with some problems (selected level) and families with severe problems (indicated level). The key is devising proper input for different levels and delivering it to target groups in suitable ways.

In developed countries like the UK, the USA, Australia, and Canada, cultivating family resources and enhancing family functioning are often the key emphases in youth drug-prevention initiatives [14]. There has been an intense focus on addressing the family-based risk and protective factors that seem to cause youth substance abuse. Reduction of risk factors, such as normalizing the lives of children suffering from parental drug use, has been reported in Australia [15]. More systematic government-led or commissioned prevention strategies can reinforce protective factors, including providing nation-wide meaningful youth engagement and strengthening the attached bonding and relationships with adults through family-based intervention like parental training. The UK [16] and Australia [17] have been especially explicit in addressing these areas. Both countries currently promote joint efforts across agencies (e.g., NGOs and the government) to assist 
at-risk families in preventing drug abuse and other social problems from spreading intergenerationally. The public health approach in the USA strives to mobilize the whole community to address the drug problem and generate behavioral changes. The use of the "Communities that Care Systems" [18] has successfully created necessary social capital to improve the environmental context which young people live in. Canada stresses youth-focused community prevention initiatives by establishing school-based, community-based, and family-based Canadian Standards.

Even with such clear theories and related research on the important role of families on child development, there are obvious barriers to enlisting parents in antidrug work $[19,20]$. Drug abuse has long been treated as the worst of the indulgent vices, especially in Chinese communities where "the war on drugs" is associated with a painful period of history in which the Chinese were plundered and exploited by other countries. There is a pervasive social taboo on even mentioning the word "drug abuse." According to a survey of 4,550 parents of senior-primary and junior-secondary students (ages 9-11 and 12-14, resp.) [20], many parents never imagine their children or any family member having the slightest chance of being affected by drug abuse. Only $26.8 \%$ reported ever noticing information that alerted parents on how to prevent or handle their children's abuse of drugs. As few as $2.1 \%$ of that sample actually participated in antidrug programs. Even if their children were already showing at-risk behavior (e.g., shop lifting or hanging around with undesirable peers), most parents in the survey chose to deny the possibility that their children could be affected by drugs, until there were physical problems arising from long-term abuse and it was too late for any intervention to be effective [3].

The 2010 report of the Narcotics Division [21] found that no school was free from student drug use. The increasingly low age of reported first drug use (as low as age nine in a 2009 case) and the intense public antidrug campaigns in Hong Kong finally convinced parents to pay more attention. Many schools found it acceptable, even progressive, to run annual educational programs to better inform parents of the nature and risks of youth drug abuse. It was also clear that parents who discovered their children's drug use, often in their own homes or at friends' homes (i.e., not at drug dens or rave parties), were shocked and desperate for advice on how to act without ruining the children's future and the parent-child relationship. Parent associations also advocated for preventive education to alert general parents who underestimated the risk of their children using drugs. The same parenting survey [20] found motivating and discouraging factors for parents' participation in drug-prevention programs. When the program provider commanded some confidence in providing a fruitful program (e.g., appropriate program publicity and supportive logistic arrangements like child care for parents with young dependent children), parents became more willing to participate, especially when their children had reached the rebellious-adolescence stage and manifested some behavior problems. The age of children also affected parents' interest in participation. Parents with younger children appeared to be more willing to put effort into helping their children. In 2009, there were heated debates in Hong Kong about whether student drug tests should be mandatory in secondary schools. The support from parents and schools in Tai Po, one of the 18 districts in Hong Kong, to join the pilot scheme was another sign that parents recognized the importance of joining the fight against youth drug use. All these prompted the government to provide more support to develop psychoeducational parent education materials on fighting youth drug abuse, and more researchers and practitioners responded to fill such local educational and service gaps.

\section{PROGRAMS TO HELP PARENTS FIGHT YOUTH DRUG USE}

In Hong Kong, the Hong Kong Narcotics Division and nongovernmental agencies have been providing various antidrug programs. However, the nature and targets of these antidrug programs are diverse and their effectiveness is rarely examined systematically. For example, among the 207 drug prevention programs subsidized by the Hong Kong Beat Drugs Fund from 1996 to 2006, only 11 (around 5\%) focused on parents as their primary target. By 2010, the proportion had risen to about $10 \%$. Typical programs include talks in schools or at community carnivals or a series of sessions on radio or television. Many are single-session mass programs on which it is difficult and/or not very meaningful to conduct impact studies. The first 
attempt to develop a parent antidrug manual was Project Mind: Astro Parents Program Manual [22]. The program drew on the Ecological Systems Theory, Social Learning Theory, Positive Psychology, and the Cognitive-behavioral Model. But the circulation of the manual was too limited to have much impact.

The second and more elaborate attempt to develop manuals to engage parents in antidrug work started in 2006, when the Beat Drugs Fund sponsored a large-scale survey on parental awareness of drug-prevention programs and on the factors that hindered/motivated parents' attendance of and benefit from such programs. The survey informed the development of the parent education package "Engagement of Parents in Antidrug work (EPA)," comprising four manuals: a general users' guide with three detailed manuals on how to run multisession parent education groups (for parents in general, parents with at-risk children, and parents with a history of drug use) to reduce parenting stress, enhance parent-child communication and relationships, and master knowledge of drug prevention and early identification. The inclusion of three target groups clearly shows that the program adopted the Public Health framework, in addition to the Ecological Systems Theory, Positive Psychology, Cognitive Behavioral Theory, and principles of early intervention.

The EPA program design was founded on the program designer's previous research and work in parent education [23] and on an updated literature review. In their landmark book published in 1984, Pugh and De'Ath [24] defined parent education as "a range of educational and supporting measures, which help parents and prospective parents to understand themselves and their children and enhance the relationship between them" (page 46). This definition rightly asserted some key principles in parent education. First, it undertook a preventive stance by including prospective parents and parents as service targets. This matches even the current trend of viewing parent education as functional on primary, secondary, and tertiary preventive levels. Second, it acknowledged the usefulness of both educational and supportive strategies to help parents and suggested that a range of activities can be equally effective in serving different parents. Third, it stressed the need for self-understanding before intervention. This assertion identified an appropriate entry point for parent education and allows for more adequate address of cultural and social diversities.

A review of local parent-education programs [23] found that parent education was delivered by an array of suppliers, ranging from private practitioners to professionals in public services, including family life education program workers before 2000, and social workers in Integrated Family Service Centres after 2000 [25-27]. Theoretical approaches (person-centered, behavioral approach, and cognitive) were popular, but they were not often used systematically. Program format also varied, from multisession closed groups to single-session workshops, lectures, or mass programs. The most common sort of data collected for program feedback was attendees' satisfaction, and there was little or no attempt at systematic evaluation.

In view of the existing needs and drawbacks of parent education, the Hong Kong government in 2001 launched a two-year project to review and develop parent education. The Parent Education Review Report [28] recommended that parent education should be a holistic reflection of the ecological and systems dynamics that impact on parenting and should be relevant to the diverse and changing concerns of the Chinese in their socialization practices [29]. At-risk families and hard-to-reach parents should be given the highest priority. Optimal use will be made of critical factors identified to be conducive to effective education: kindling parental commitment, promoting school involvement, improving of personnel quality through continuous training, and developing/evaluating systematically designed programs. The review also engineered the introduction of Sander's Triple-P program [30], a well-researched Australian parent education package involving multidisciplinary team and multilevel intervention modes of service delivery, into maternity services of the Health Department. A locally developed and tested parent education program was also created for use in primary schools. However, there was no systematic support for education of secondary school parents, and certainly not on specific topics like drug prevention.

The EPA program represented the first government-commissioned project to develop a theory-driven local parent education package with efficacy evidence to support general parents, parents at risk, and parents with drug-use history (Table 1). It referenced literature [31-33] which further specified that successful parent education programs should meet four key criteria: (a) design and content should be theory-driven, comprehensive, actively engaging, and of sufficient dosage and intensity; (b) program should be age, gender, and culture sensitive, (c) implementation should be supported by well-qualified personnel who have good 
TABLE 1: Core components of the 3-level parent education program.

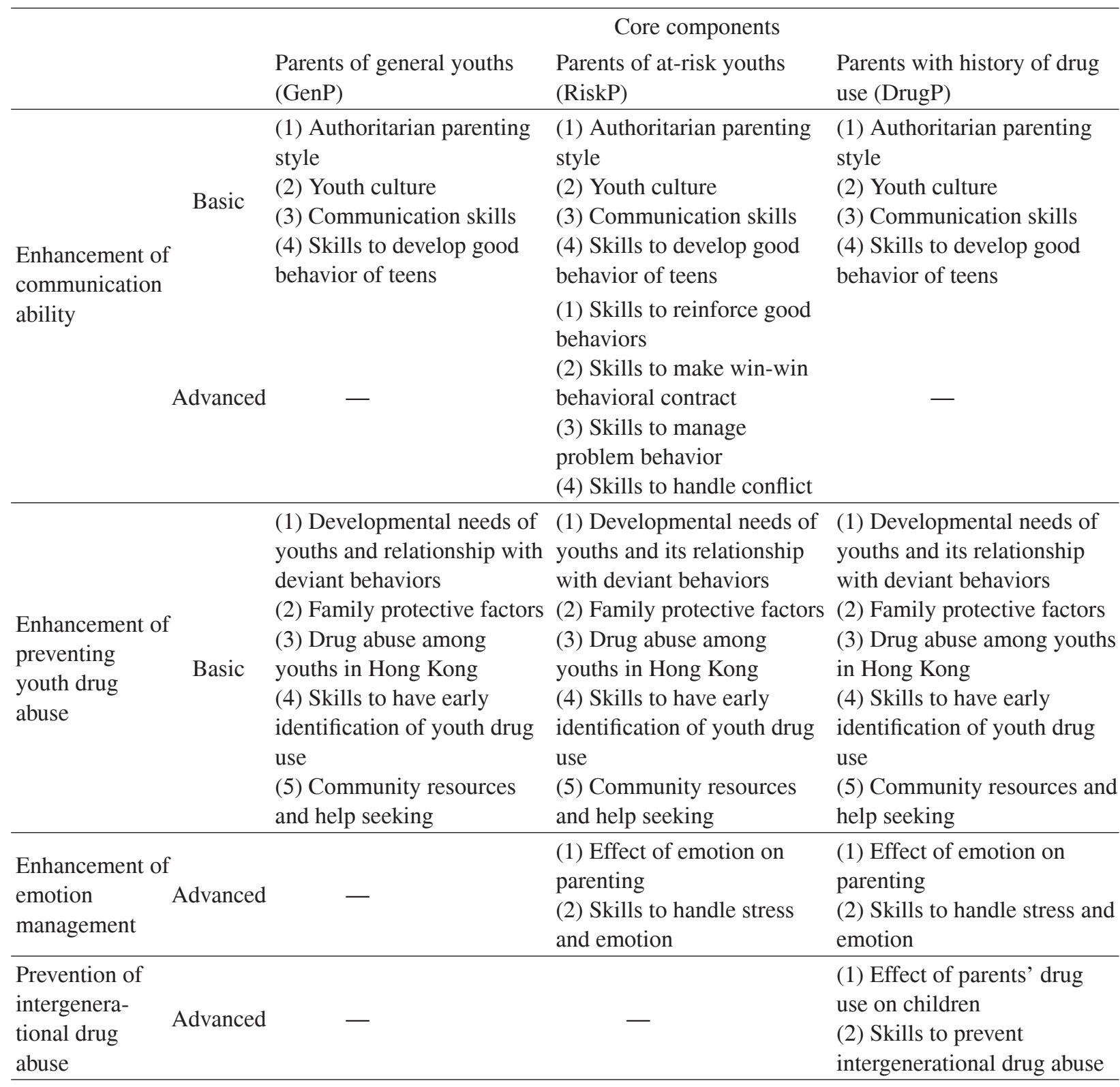

relationships with the participants and conduct the programs at accessible times and venues, and (d) quality should be documented and assessed for quality assurance and refinement.

Program efficacy was established through randomized control trial studies on all three types of parents. Altogether 437 people (128 general parents, 243 parents with adolescent children at risk of problem behavior, and 66 parents with drug use history) in 44 groups completed a total of 140 group sessions. Program efficacy results were based on measures like the parenting stress scale, dyadic relationship with child subscale, self-efficacy in child management, parenting competence, family cohesion, and knowledge of and attitudes toward drugs [20]. These measures indicated that the program reduced parenting stress and enhanced parent-child relationship, parental competence, and knowledge of drugs and prevention. The encouraging evidence from the project attracted funding to convert the manuals into a resources kit for parent educators [34]. In 2009-2010, over 10,000 kits were distributed for use in schools and social-service agencies, and a website with regular updates was established for on-going public education. The project also 
reached close to 1,000 practitioners who were interested in delivering the program to parents in their service settings. The principal investigator in these two projects further participated in a consultancy study which was commissioned by the Central Policy Unit to make proposals to the Family Council on family factors in youth drug abuse and on strategies for effective prevention [14]. This series of studies demonstrated how program-based research can eventually inform policy development.

\section{LIMITATIONS, CHALLENGES, AND WAY FORWARD}

This exciting development of indigenous resources to help parents engage in antidrug work needs to be sustained through adequate funding to address some of the limitations in these studies. There should be support to help parent-education personnel deliver, evaluate, and improve on such programs. There should be provision for longitudinal and territory-wide studies like those in other countries [15] to examine the long-term effect of such programs, and their generalizability to parents with different socioeconomic backgrounds. The sample size should be expanded, and more fathers should be engaged as participants. The differential effectiveness of using the resource kit materials in casework, group work, mass programs, and in the online mode should also be established. New evidence-based programs with specific foci, like helping parents to effectively handle the shock of realizing their children's drug-use problem, should be developed to fill the current knowledge and service gaps.

Unfortunately, the open bidding system in public research funds makes it very difficult for researchers to follow through on these necessary research lines. The sudden and overwhelming attention on youth drug-prevention studies and services has also made the community rather confused and less receptive to further studies on the subject. However, the affordability and easy accessibility of modern forms of drugs, the convenience of consumption, and the deceivingly gentle erosion of physical health and creeping dependency do culminate in the normalization of drug use for recreation and relaxation [4]. This trend, coupled with the exhausting life style of parents and young people, reduction of family solidarity [35], and a cultural preference to deny rather than face up to emergent drug abuse problems, poses a continuous and concrete threat - the breeding of an even more serious drug abuse problem not just among young people, but also among younger working adults. Even when theory-driven and evidence-based local resources to develop positive youths, healthy schools, and competent parents [36] have been developed, there is no room for complacency. There should be continuous effort to ensure that such wisdom can effectively inform relevant policies and service planning to make it possible for young people to enjoy healthy development and potential-enhancing education and for parents to enjoy family-friendly work policies so that they can cultivate quality relationships with their children.

Another promising line for advancing parent education in preventing youth drug use is the development of antidrug programs for parents parallel with positive youth development programs like Project P.A.T.H.S. (Positive Adolescent Training through Holistic Social Programmes), especially when its Extension Phase features 20 drug-education units (Table 2). Project P.A.T.H.S., like the EPA, is informed by cognitive behavioral theories and works through carefully designed program activities, processes, and discussion to achieve intended gains in knowledge, attitude, and skills of self-understanding, emotional control, discernment of right and wrong, and self-efficacy. The units in the Extension Phase target the specific and different developmental needs of Secondary 1, 2, and 3 students. Parents enlightened to the structure and content of such units should develop greater empathy toward their children's struggles in dealing with the tempting push-pull dynamics from peers.

However, secondary school students are often eager to establish their own identity through mingling with peers and distancing themselves from parents. Attending parallel training programs with their parents, and with their schoolmates and their parents, might not be very appealing [37]. To overcome such hurdles, Tsang and T. W. G. Hs [20] found that convenient program times and venues, convincing program presenters, and solid program content can still attract participants. In addition, both programs are available in hard copy and are supported by actively updated websites, catering for the different learning modes of modern parents and teenagers. Given the generally enhanced attention to antidrug information, and the 
TABLE 2: The 20 drug-education units in the P.A.T.H.S. Extension Phase.

\begin{tabular}{|c|c|c|c|}
\hline Unit code & Unit & Unit aims & Learning targets \\
\hline AD1.1 & $\begin{array}{l}\text { Choosing a } \\
\text { Better Way }\end{array}$ & $\begin{array}{l}\text { To enable students to understand that } \\
\text { emotions may affect our ability to solve } \\
\text { problems, and thus lead to different } \\
\text { consequences }\end{array}$ & $\begin{array}{l}\text { (1) To understand the relationship between } \\
\text { coping methods and consequences } \\
\text { (2) To analyze the influences of different } \\
\text { coping methods }\end{array}$ \\
\hline AD1.2 & $\begin{array}{l}\text { Emotion, } \\
\text { Your Name } \\
\text { Is ... }\end{array}$ & $\begin{array}{l}\text { To help students understand their emotions, } \\
\text { identify different emotional states caused by } \\
\text { different conditions, and realize that } \\
\text { individuals in certain emotional states are } \\
\text { easily influenced by drugs }\end{array}$ & $\begin{array}{l}\text { (1) To enhance the ability to articulate and } \\
\text { identify emotions through games. } \\
\text { (2) To identify various emotional states and } \\
\text { their causes }\end{array}$ \\
\hline AD 1.3 & $\begin{array}{l}\text { Emotional } \\
\text { Survival } \\
\text { Guide }\end{array}$ & $\begin{array}{l}\text { To understand that choosing a smarter } \\
\text { coping method can make life better }\end{array}$ & $\begin{array}{l}\text { (1) To explore different coping methods } \\
\text { (2) To identify the benefits and drawbacks of } \\
\text { different coping methods } \\
\text { (3) To analyze the use of drugs as a coping } \\
\text { method }\end{array}$ \\
\hline AD 1.4 & $\begin{array}{l}\text { Facts Are } \\
\text { Facts }\end{array}$ & $\begin{array}{l}\text { To understand that clarifying facts is the first } \\
\text { step of critical thinking }\end{array}$ & $\begin{array}{l}\text { (1) To understand that "clarifying facts" is } \\
\text { the base of critical thinking and can help us } \\
\text { make reasonable conclusions and take } \\
\text { reasonable actions } \\
\text { (2) To identify facts about drugs and analyze } \\
\text { the possible harm caused }\end{array}$ \\
\hline $\mathrm{AD} 1.5$ & $\begin{array}{l}\text { At Sixes and } \\
\text { Sevens }\end{array}$ & $\begin{array}{l}\text { To encourage students when they face peer } \\
\text { pressure }\end{array}$ & $\begin{array}{l}\text { (1) To understand that people around us will } \\
\text { try to influence our thinking, attitudes, and } \\
\text { behaviors through different techniques } \\
\text { (2) To be aware of the necessity of using } \\
\text { critical thinking when facing the above } \\
\text { situations }\end{array}$ \\
\hline
\end{tabular}

(1) To learn about four major types of personality

AD1.6 Find a Good own personality and to investigate the effect

(2) To understand the effects of personality Friend of personality on interpersonal relationships on interpersonal relationships and review their own personality and individual behavior (including illegal behavior)

\begin{tabular}{|c|c|c|c|}
\hline \multirow{3}{*}{ AD1.7 } & \multirow{3}{*}{$\begin{array}{l}\text { Say No to } \\
\text { Undesirable } \\
\text { Friends }\end{array}$} & & \multirow[b]{2}{*}{$\begin{array}{l}\text { (1) To identify the determinants for desirable } \\
\text { and undesirable friends }\end{array}$} \\
\hline & & $\begin{array}{l}\text { (1) To show students how to recognize } \\
\text { desirable friends from undesirable ones and } \\
\text { encourage them to choose the right friends } \\
\text { and establish a healthy relationship }\end{array}$ & \\
\hline & & $\begin{array}{l}\text { (2) To show students the required skills to } \\
\text { resist temptation }\end{array}$ & (2) To practice refusal principles and skills \\
\hline AD 1.8 & $\begin{array}{c}\text { What Should } \\
\text { I Do? }\end{array}$ & $\begin{array}{l}\text { To explore vital areas in decision making in } \\
\text { order to be able to make positive decisions in } \\
\text { daily life }\end{array}$ & $\begin{array}{l}\text { To learn that one should consider and } \\
\text { analyze others' opinions and the } \\
\text { consequences of making a choice }\end{array}$ \\
\hline AD2.1 & Is It Okay? & $\begin{array}{l}\text { To let students understand and encourage } \\
\text { students to observe the clear, positive, } \\
\text { healthy, and ethical standards in the } \\
\text { community }\end{array}$ & $\begin{array}{l}\text { (1) To learn that society holds different } \\
\text { standards towards different people/issues } \\
\text { (2) To understand that the use of } \\
\text { psychotropic drugs is inconsistent with } \\
\text { standards of social behavior }\end{array}$ \\
\hline
\end{tabular}


TABLE 2: Continued.

\begin{tabular}{|c|c|c|c|}
\hline Unit code & Unit & Unit aims & Learning targets \\
\hline $\mathrm{AD} 2.2$ & $\begin{array}{l}\text { Is It Right or } \\
\text { Wrong to } \\
\text { Follow the } \\
\text { Trend? }\end{array}$ & $\begin{array}{l}\text { To distinguish the expectations of the society } \\
\text { towards conforming behaviors }\end{array}$ & $\begin{array}{l}\text { (1) To understand that the society expects } \\
\text { people with different ages and identities } \\
\text { adopt appropriate conforming behaviors } \\
\text { (2) To understand the fact that conforming } \\
\text { behaviors can be good or bad } \\
\text { (3) To understand the importance of not } \\
\text { following trends blindly but making rational } \\
\text { choices }\end{array}$ \\
\hline AD2.3 & $\begin{array}{l}\text { What Are } \\
\text { Frustrations? }\end{array}$ & $\begin{array}{l}\text { To reconstruct students' awareness of what } \\
\text { frustrations are and to let them understand } \\
\text { how to learn from the experience of } \\
\text { frustrations }\end{array}$ & $\begin{array}{l}\text { (1) To understand how to face failures } \\
\text { (2) To find out the learning points from the } \\
\text { experience of frustrations }\end{array}$ \\
\hline AD2.4 & $\begin{array}{l}\text { General's } \\
\text { Choice }\end{array}$ & $\begin{array}{l}\text { To learn that we should not accept any } \\
\text { temptations when we are facing difficulties } \\
\text { just to obtain excitement but creating greater } \\
\text { problems for the future }\end{array}$ & $\begin{array}{l}\text { (1) To understand the luring effects of } \\
\text { temptations and how to reject them } \\
\text { (2) To stay away from short-term happiness } \\
\text { that comes from avoidance of adversity }\end{array}$ \\
\hline AD2.5 & Think Twice! & $\begin{array}{l}\text { To enhance students' competence in } \\
\text { self-determination by sharpening their } \\
\text { decision-making skills }\end{array}$ & $\begin{array}{l}\text { (1) To sharpen decision-making skills } \\
\text { (2) To handle peer pressure by making use of } \\
\text { decision-making skills } \\
\text { (3) To understand that each person should be } \\
\text { responsible for his/her decisions and accept } \\
\text { the consequences }\end{array}$ \\
\hline AD2.6 & $\begin{array}{l}\text { I Am } \\
\text { Precious! }\end{array}$ & $\begin{array}{l}\text { To rediscover self-worth, as a means of } \\
\text { resisting the temptation to take drugs }\end{array}$ & $\begin{array}{l}\text { (1) To understand that everyone is unique } \\
\text { (2) To understand that each person can } \\
\text { overcome the past and rediscover their } \\
\text { self-worth and direction in life } \\
\text { (3) To discover one's strengths and } \\
\text { uniqueness }\end{array}$ \\
\hline AD3.1 & $\begin{array}{l}\text { Opium- } \\
\text { Trade-War }\end{array}$ & $\begin{array}{l}\text { To reflect on how we can contribute to a } \\
\text { society that is being harmed }\end{array}$ & $\begin{array}{l}\text { (1) To know the stories of some "nobodies" } \\
\text { in Chinese history and cultivate our sense of } \\
\text { responsibility when facing social problems } \\
\text { today } \\
\text { (2) To think about our own roles when the } \\
\text { community is being harmed }\end{array}$ \\
\hline AD3.2 & $\begin{array}{l}\text { Encountering } \\
\text { a Friend }\end{array}$ & $\begin{array}{l}\text { To facilitate students' empathetic } \\
\text { understanding of others and to encourage } \\
\text { them to help themselves and others when } \\
\text { there are problems caused by emotions }\end{array}$ & $\begin{array}{l}\text { (1) To empathize with others' emotions and } \\
\text { realize those emotions may be ways of } \\
\text { adapting to life } \\
\text { (2) To support those facing emotional } \\
\text { problems, in order to reduce their need for } \\
\text { drugs }\end{array}$ \\
\hline AD3.3 & $\begin{array}{l}\text { Believe It or } \\
\text { Not }\end{array}$ & $\begin{array}{l}\text { To facilitate students use of critical thinking, } \\
\text { realize there are various causes of deviant } \\
\text { behavior, and help students enhance their } \\
\text { empathy for parents }\end{array}$ & $\begin{array}{l}\text { (1) To enhance critical-thinking abilities } \\
\text { (2) To reflect parents' role and limitations in } \\
\text { improving teenagers' deviant behavior, in } \\
\text { order to empathize with parents }\end{array}$ \\
\hline
\end{tabular}


TABLE 2: Continued.

\begin{tabular}{llll}
\hline Unit code & \multicolumn{1}{c}{ Unit } & Unit aims & Learning targets \\
\hline AD3.4 & $\begin{array}{l}\text { This Is My } \\
\text { Badge }\end{array}$ & $\begin{array}{l}\text { To assist students to establish positive and } \\
\text { feasible objectives of life in order to } \\
\text { understand that they have ability to face } \\
\text { challenges and enrich their life }\end{array}$ & $\begin{array}{l}\text { (1) To consider which characteristics can let } \\
\text { them better face challenges in life and not to } \\
\text { solve problems by abusing drugs } \\
\text { (2) To enhance students confidence and } \\
\text { expectation in nurturing their good quality } \\
\text { through creative activities }\end{array}$ \\
\hline AD3.5 & $\begin{array}{l}\text { The New } \\
\text { Biography of } \\
\text { Sisyphus }\end{array}$ & $\begin{array}{l}\text { To cultivate the ability to face and handle } \\
\text { miseries and adversities }\end{array}$ & $\begin{array}{l}\text { (1) To explore how to face miseries and } \\
\text { adversities }\end{array}$ \\
& & $\begin{array}{l}\text { (2) To understand that our mind affects our } \\
\text { behavior; positive thinking may help us } \\
\text { figure out positive and effective ways to } \\
\text { solve our problems }\end{array}$ \\
\hline \multirow{2}{*}{$\begin{array}{l}\text { A U-Turn of } \\
\text { Life }\end{array}$} & $\begin{array}{l}\text { To understand that there is always way out in } \\
\text { adversities. Do not use negative ways to } \\
\text { "solve" problems at times of difficulties }\end{array}$ & $\begin{array}{l}\text { To understand that every person has choices } \\
\text { and is able to find positive solutions at times } \\
\text { of difficulties }\end{array}$ \\
\hline
\end{tabular}

diminishing taboo attached to attending antidrug programs [38], some parent-teacher associations in some schools and some social service centers have started incorporating drug-prevention psychoeducation into family camps and volunteer service projects. A recent positive youth development community study in one district of Hong Kong also recommended that programs can be created to incorporate ideas from the EPA and the Project P.A.T.H.S. Extension Phase to enhance the healthy development of young people [38]. The parent and adolescent parallel units should be synchronized more systematically after initial evidence is available on the units of the P.A.T.H.S. Extension Phase.

\section{CONCLUSION}

Parents are essential but long-neglected stakeholders in the campaign against youth drug use. Still, parent engagement in drug prevention in Hong Kong, and probably in other Chinese communities, is showing some promising results. Given the important role played by parents in holistic positive youth development and also in drug-prevention, there is an obvious need to sustain the efforts to develop more theory-driven and evidence-based parent programs and to train more competent parent education personnel in this specific area. Aside from developing strong parent education programs, parent-adolescent parallel programs can also be considered, especially in the light of the availability of strong parent and adolescent-based programs.

\section{ACKNOWLEDGMENT}

The preparation of this paper and the Project P.A.T.H.S. were financially supported by The Hong Kong Jockey Club Charities Trust.

\section{REFERENCES}

[1] Barnabas Charitable Service Association Limited, Survey Report on the Drug-Taking Attitude of Senior Primary School Students, Barnabas Charitable Service Association Limited, Hong Kong, 2009.

[2] Hong Kong Narcotics Division, "The 2008/09 survey of drug use among students," Hong Kong Narcotics Division, 2010, http://www.nd.gov.hk/en/survey_of_drug_use.htm. 
[3] S. K. M. Tsang, S. Tse, H. M. C. Wong, and S. J. Zhu, "Study of young people's attitude toward prevention of drug addiction and mental health promotion in the Southern District," Commissioned by the Southern District Anti-drug Addiction Community Consortium, Hong Kong Special Administrative Region, 2010, http://www.socialwork.hku.hk/people/staff/files/attachment/20101119095721.pdf.

[4] N. W. T. Cheung and Y. W. Cheung, "Is Hong Kong experiencing normalization of adolescent drug use? Some reflections on the normalization thesis," Substance Use and Misuse, vol. 41, no. 14, pp. 1967-1990, 2006.

[5] Hong Kong Lutheran Social Service, Doing Gender: Engendering Drug Use Patterns among Females in Hong Kong, Hong Kong Lutheran Social Service, Hong Kong, 2010.

[6] Sing Pao, "Guys courted gals with drugs Number of female drug addicts first exceed male," 2010, http://www.singpao.com/newsarticle.aspx?NewsID=106528\&Lang=tc.

[7] S. K.M. Tsang, E. K.P. Hui, D. T.L. Shek, and B. C.M. Law, "Subjective outcome evaluation of the project P.A.T.H.S.: findings based on the perspective of the program implementers (secondary 1 program)," TheScientificWorldJOURNAL, vol. 10, pp. 201-210, 2010.

[8] Hong Kong Narcotics Division, “Anti-drug policy," 2010, http://www.nd.gov.hk/tc/antidrugstrategy.htm.

[9] U. Bronfenbrenner, The Ecology of Human Development: Experiments by Nature and Design, Harvard University Press, Cambridge, Mass, USA, 1979.

[10] R. F. Catalano, M. L. Oxford, T. W. Harachi, R. D. Abbott, and K. P. Haggerty, "A test of the social development model to predict problem behaviour during the elementary school period," Criminal Behaviour and Mental Health, vol. 9, no. 1, pp. 39-56, 1999.

[11] J. D. Hawkins, R. F. Catalano, and J. Y. Miller, "Risk and protective factors for alcohol and other drug problems in adolescence and early adulthood: implications for substance abuse prevention," Psychological Bulletin, vol. 112, no. 1, pp. 64-105, 1992.

[12] Community Anti-Drug Coalitions of America (CADCA), "The coalition impact: environmental prevention strategies. Beyond the basics: topic-specific publications for coalitions," 2008, http://www.cadca.org/files/Beyond_the_ Basics_EnvironmentalStrategies.pdf.

[13] R. Gordon, "An operational classification of disease prevention," in Preventing Mental Disorders, J. A. Steinberg and M. M. Silverman, Eds., pp. 20-26, Department of Health and Human Services, Rockville, Md, USA, 1987.

[14] S. K. M. Tsang and E. Tong, Report on a Study on Drug Abuse among Youths and Family Relationship, The University of Hong Kong, Hong Kong, 2010, Policy recommendation commissioned by Central Policy Unit, Hong Kong SAR Government.

[15] S. Dawe, S. Frye, D. Best et al., Drug use in the family: impacts and implications for children, Australian National Council on Drugs, Australia, 2006.

[16] Department for Children, School and Families (DCSF), “Substance misuse," 2008, http://www.dcsf.gov.uk/ everychildmatters/healthandwellbeing/commonhealthissues/substancemisuse/substancemisuse.

[17] Minister for Families, Housing, Community Services and Indigenous Affairs (FaHCSIA), "Helping families affected by drug abuse," 2008, http://www.jennymacklin.fahcsia.gov.au/mediareleases/2008/Pages/helping_ families_23apr08.aspx.

[18] Substance Abuse and Mental Health Services Administration (SAMHSA), "SAMHSA's prevention platform," 2004, http://prevention.samhsa.gov/about/spf.aspx.

[19] Social Care Institute for Excellence, "At a glance 11: reaching parents: implementing parenting programmes," 2009, http://www.scie.org.uk/publications/ataglance/ataglance11.asp.

[20] S. K. M. Tsang and T. W. G. Hs, "Engagement of parents in anti-drug work: research report and four program manuals on implementation guidelines, prevention programmes for general parents, parents with at risk children and parents with drug-taking history," Commissioned by Narcotics Division, Hong Kong SAR Government, 2008, http://www.nd.gov.hk/pdf/EPA_Full_Report.pdf.

[21] Narcotics Division, "The 2008/09 survey of drug use among students," Government of the Hong Kong Special Administrative Region, 2010, http://www.nd.gov.hk/en/survey_of_drug_use.htm.

[22] D. O. B. Lam, H. Y. Ng, D. L. Shek et al., Project Mind: Astro Parents Program Manual, Beat Drug Fund Association, Hong Kong, 2003.

[23] S. K. M. Tsang, "Parent education in Hong Kong and implications for pediatricians," Hong Kong Journal of Pediatrics, vol. 9, pp. 176-185, 2004. 
[24] G. Pugh and E. De'Ath, The Needs of Parents: Practice and Policy in Parent Education, Macmillan Education Ltd, Basingstoke, UK, 1984.

[25] S. K. M. Tsang and Consultancy Team, Meeting the Challenge: Strengthening Families. Review of Family Services in Hong Kong, The University of Hong Kong, Hong Kong, 2001, Commissioned by the Social Welfare Department, Hong Kong SAR Government.

[26] S. K. M. Tsang and Consultancy Team, The Step Forward: The Formation of Integrated Family Service Centres: Final Report on the Implementation of the Family Service Review, The University of Hong Kong, Hong Kong, 2005, Commissioned by the Social Welfare Department, Hong Kong SAR Government.

[27] S. K. M. Tsang and Consultancy Team, Building Effective Family Services: Review on the Implementation of the Integrated Family Service Centre Service Mode, The University of Hong Kong, Hong Kong, 2010, Commissioned by the Social Welfare Department, Hong Kong SAR Government.

[28] Chinese University of Hong Kong, The Promotion of Parent Education in Hong Kong: A Consultancy Study Final Report (Executive summary), Authors, Hong Kong, 2001.

[29] S. Lau and P. P. W. Yeung, "Understanding Chinese child development: the role of culture in socialization," in Growing up the Chinese Way: Chinese Child and Adolescent Development, S. Lau, Ed., pp. 29-44, The Chinese University Press, Hong Kong, 1996.

[30] M. R. Sanders, "Triple P-positive parenting program: towards an empirically validated multilevel parenting and family support strategy for the prevention of behavior and emotional problems in children," Clinical Child and Family Psychology Review, vol. 2, no. 2, pp. 71-90, 1999.

[31] L. Dusenbury, "Family-based drug abuse prevention programs: a review," Journal of Primary Prevention, vol. 20, no. 4, pp. 337-353, 2000.

[32] M. Nation, C. Crusto, A. Wandersman et al., "What works in prevention: principles of effective prevention programs," American Psychologist, vol. 58, no. 6-7, pp. 449-456, 2003.

[33] S. A. Small, S. M. Cooney, and C. O\&\#x27;Connor, "Evidence-informed program improvement: using principles of effectiveness to enhance the quality and impact of family-based prevention programs," Family Relations, vol. 58, no. 1, pp. 1-13, 2009.

[34] S. K. M. Tsang and T. W. G. Hs, Engagement of Parents in Anti-Drug Work: Research Kit with Four Program Manuals on Implementation Guidelines and Prevention Programmes for General Parents, Parents with at Risk Children and Parents with Drug-Taking History, 2009, Commissioned by Narcotics Division, Hong Kong SAR Government.

[35] The Hong Kong Council of Social Service, "Social indicators report," 2010, http//www.hkcss.org.hk/index_e.asp.

[36] S. K. M. Tsang and C. Leung, "Developing a database for evaluating the effectiveness of parent education and support programs: results of a pilot study," Illinois Child Welfare Journal, vol. 2, no. 1-2, pp. 77-89, 2005.

[37] M. J. Fine and S. W. Lee, Eds., Handbook of Diversity in Parent Education: The Changing Faces of Parenting and Parent Education, Academic Press, San Diego, Calif, USA, 2001.

[38] S. K. M. Tsang, S. Tse, H. M. C. Wong, and S. J. Zhu, "Study of young people's attitude toward prevention of drug addiction and mental health promotion in the Southern District," Southern District Anti-drug Addiction Community Consortium, Hong Kong Special Administrative Region, The University of Hong Kong, Hong Kong, 2010, http://www.socialwork.hku.hk/people/staff/files/attachment/20101119095721.pdf.

\section{This article should be cited as follows:}

Sandra K. M. Tsang, "Parent Engagement in Youth Drug Prevention in Chinese Families: Advancement in Program Development and Evaluation,” TheScientificWorldJOURNAL, vol. 11, pp. 2299-2309, 2011. 